\title{
Effects of inclusion of patauá, Oenocarpus bataua meal on elephant grass silage
} \author{
DOMINGUES $^{1}$, Aníbal Coutinho do REGGO ${ }^{1^{*}}$ (])

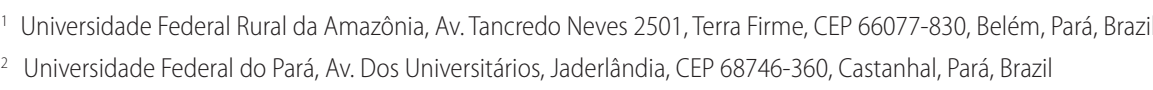

Amanda Caroliny Marques de QUEIROZ1, Wânia Mendonça dos SANTOS², Rita de Cássia Almeida de MENDONÇA ${ }^{1}$, Rosana Ingrid Ribeiro dos SANTOS ${ }^{1}$, Thiago Carvalho da SILVA ${ }^{1}$, Felipe Nogueira

\section{ABSTRACT}

Elephant grass silages have high moisture content, causing nutrient loss, mainly by effluent production. The use of moisture absorbent additives, such as patauá, Oenocarpus bataua meal, can be a strategy to reduce losses in these silages. The aim of this study was to determine the fermentation losses, microbiological composition, fermentative characteristics, and chemical composition of elephant grass silage with increasing levels of inclusion of patauá meal. The experiment was conducted in a completely randomized design, with four concentrations of patauá meal $(7 \%, 14 \%, 21 \%$, and $28 \%$, based on fresh matter) and a control without patauá, and five replicates. The elephant grass was collected manually after 60 days of growth. After chopping, the grass was homogenized, mixed with the pataua meal according to the established treatments, and ensiled in experimental silos of $15 \mathrm{~L}$. The inclusion of patauá meal in elephant grass silage had positive effects on the chemical composition and effluent loss. It significantly increased dry matter, organic matter, crude protein, nitrogen insoluble in neutral detergent and acid, ethereal extract, lignin, and non-fibrous carbohydrates of the silages. It also reduced effluent losses, neutral and acid detergent fiber contents, and cellulose. Our findings contribute towards reducing the environmental impact caused by the production of effluents during ensilage of tropical grasses and providing a potential use for the residue from the production of patauá oil, thus avoiding disposal in the environment.

KEYWORDS: additive, effluent production, moisture, Pennisetum purpureum

\section{Efeitos da inclusão de torta de patauá, Oenocarpus bataua em silagens de capim elefante}

\section{RESUMO}

As silagens de capim elefante têm alto teor de umidade, que ocasiona perda de nutrientes, principalmente pela produçấo de efluentes. $\mathrm{O}$ uso de aditivos absorventes de umidade, como a torta de patauá, Oenocarpus bataua, pode ser uma estratégia para reduzir as perdas nessas silagens. Assim, objetivou-se determinar as perdas fermentativas, composição microbiológica, características fermentativas e composição química em silagens de capim elefante com níveis crescentes de inclusão de torta de patauá. O experimento foi conduzido em delineamento inteiramente casualizado, com quatro concentraçóes de torta de patauá $(7 \%, 14 \%, 21 \%$ e $28 \%$, com base na matéria natural) e um controle sem patauá, e cinco repetiçóes. O capim elefante foi coletado aos 60 dias de crescimento. Após o corte, o capim foi homogeneizado, misturado com a torta de patauá de acordo com os tratamentos estabelecidos, e ensilado em silos experimentais de $15 \mathrm{~L}$. A inclusão da torta de patauá em silagens de capim elefante teve efeitos positivos sobre a composiçáo química e as perdas por efluentes. Houve aumento significativo de matéria seca, matéria orgânica, proteína bruta, nitrogênio insolúvel em detergente neutro e ácido, extrato etéreo, lignina e carboidratos não fibrosos das silagens. Além disso, houve redução de perdas por efluentes, teor de fibra em detergente neutro e ácido, e celulose das silagens. Nossos resultados contribuem para a redução de impactos ambientais gerados pela produção de efluentes no processo de ensilagem de gramíneas tropicais e fornecem uma utilidade potencial para o resíduo da produção de óleo de patauá, evitando o descarte no meio ambiente.

PalaVRas-CHAVE: aditivo, Pennisetum purpureum, produção de efluente, umidade 


\section{INTRODUCTION}

Elephant grass, Pennisetum purpureum Schum. is one of the tropical forage grasses that are used for silage production in Brazil (Lima Júnior et al. 2014). However, when it is harvested for silage production (after 60 days of growth), there is no balance between the production and the nutritive value (Rêgo et al. 2010). This owes to characteristics of the grass that limit conservation during silage production, such as low dry matter content (15\% to $20 \%$ ), water-soluble carbohydrates content below $15 \%$, and high buffering capacity (Bernardes et al. 2018). The high moisture content of tropical grasses favors effluent production, causing nutrient losses during the production of silage (Tomaz et al. 2018). Notably, as a potential pollutant, the production of effluents is one of the main environmental issues directly associated with silage production (Gebrehanna et al. 2014; Daniel et al. 2019).

The use of moisture absorbent additives is a strategy recommended for producing tropical grass silage with minimum effluent production and improved chemical composition, intake, and dry matter digestibility (Daniel $e t$ al. 2019). The by-products of the extraction of oil from fruits of oleaginous plants are characterized by a high dry matter content $(>85 \%)$, and, when included in elephant grass silage as additives, they improve fermentation and the silage nutritive value (Menezes et al. 2016; Santos et al. 2014; Ribeiro et al. 2014; Van Cleef et al. 2012).

In the Brazilian Amazon region, the agro-industry of the seed oil of the palmtree known as patauá, Oenocarpus bataua Mart. (Arecaceae) is an important economic activity (Rodrigues et al. 2010). The patauá palmtree reaches approximately $26 \mathrm{~m}$ in height and is a monocaule palm, producing about $11 \mathrm{t}$ of fruit year ${ }^{-1}$ (Hidalgo et al. 2016). The fruits take 10 to 14 months to develop and be ready for harvest. They have an oval shape, with pulp that can be white, greenish, or purple (Seixas et al. 2015). Oil is extracted from these fruits, and used in medicines, cosmetics, and food (Souza et al. 2012). The residual product of the oil extraction process is known as patauá meal (Ramalho and Suarez 2013), consisting of unused parts of the fruit (peel, endocarp, and seed), which has no added value for agro-industries and is hence discarded.

With a dry matter content above $85 \%$, patauá meal is a potential moisture-absorbing additive for elephant grass silage. However, there are no studies on the efficacy of pataua meal in reducing fermentation losses and improving the chemical composition of silages. Therefore, this study aimed to determine the effects of the inclusion of different proportions of patauá meal during ensiling of elephant grass on fermentative losses, microbiological composition, fermentative characteristics, and chemical composition of silages.

\section{MATERIAL AND METHODS}

\section{Study site}

The experiment was conducted at Universidade Federal Rural da Amazônia - UFRA (Belém, Pará state, Brazil; 127'07"S, $48^{\circ} 26^{\prime} 13^{\prime \prime} \mathrm{W}$, altitude of approximately $11 \mathrm{~m}$ ). The climate in the region is classified as Af (tropical humid), according to the Köppen classification system, with an average annual precipitation of $2774.3 \mathrm{~mm}$ (Alvares et al. 2014).

\section{Procedures and experimental design}

We used four levels of inclusion of patauá meal $(7 \%, 14 \%$, $21 \%$, and $28 \%$, based on fresh matter, FM) added while ensiling elephant grass, and a control of elephant grass ensilaged without patauá, with five replicates per treatment. The elephant grass used in the experiment was manually collected at 60 days of development, and processed in a stationary chopper, regulated to obtain a theoretical particle size of $1 \mathrm{~cm}$. The patauá meal was obtained from the agroindustry Amazon Oil, located in Ananindeua, Pará, and consisted of the seed residues after the extraction of oil by mechanical pressing. After processing, the by-product was stored outdoors. Before ensiling, the grass and meal were sampled for chemical characterization of the material (Table 1). These analyses were carried out at the Animal Nutrition Laboratory of UFRA, following the methodology described below in "chemical composition".

Plastic containers with a capacity of $15 \mathrm{~L}$ were used as experimental silos, containing approximately $3 \mathrm{~kg}$ of dry sand each, covered with a cotton cloth to enable the measurement of the effluent produced. The silos were weighed prior to the experiment to determine the amount of effluent produced by the silage through weight difference at the end of the experiment. The patauá meal was mixed manually with the elephant grass, according to each treatment concentration. Subsequently, $15 \pm 1 \mathrm{~kg}$ of the mixture was weighed and then compacted into each of the silos, until a density of approximately $600 \mathrm{~kg} \mathrm{~m}^{-3}$ (based on fresh weight) was reached. The silos were then sealed, weighed, and stored in a closed

Table 1. Chemical composition of elephant grass (Pennisetum purpureum) and patauá (Oenocarpus bataua) meal samples used in this study.

\begin{tabular}{lcc}
\hline Parameter (\%DM) & Elephant grass & Patauá meal \\
\hline Dry matter (\%FM) & 18.7 & 89.6 \\
\hline Organic matter & 94.2 & 97.3 \\
Crude protein & 8.9 & 7.1 \\
Ether extract & 1.9 & 6.4 \\
Neutral detergente fiber & 64.9 & 57.5 \\
Acid detergente fiber & 47.6 & 36.6 \\
Hemicellulose & 19.0 & 23.5 \\
Lignin & 9.1 & 15.9 \\
Cellulose & 38.5 & 22.8 \\
Non- fibrous carbohydrates & 16.8 & 21.7 \\
\hline
\end{tabular}


room $\left(28.1 \pm 0.9{ }^{\circ} \mathrm{C}\right)$ for $990 \mathrm{~d}$. The experimental units remained in the same position over the storage period. At the end of the storage period, the silos were again weighed to quantify the gas loss (GL) and dry matter recovery (DMR). The containers were unloaded, and the silages were separated from the deteriorated portion. The silos and sand were weighed for the calculation of the effluent loss (EL). The fermentative losses in the silages were estimated using the equations proposed by Jobim et al. (2007).

\section{Microbial populations and fermentation profile}

For microbiological evaluation, $25 \mathrm{~g}$ of the silage was collected from each experimental unit. The evaluation was conducted using an aqueous extract formed from $25 \mathrm{~g}$ of silage and 225 $\mathrm{mL}$ of peptone water, homogenized manually for $3 \mathrm{~min}$. For the yeast and mold counts, dilutions of $10^{-1}$ to $10^{-2}$ were prepared; from these dilutions, the seeding was performed using the surface plating technique with Potato Dextrose Agar culture medium (Sigma-Aldrich Brasil Ltda). After incubation in a germination chamber (BIOFOCO-BF2 CGFP 275) at a temperature of $26^{\circ} \mathrm{C}$ for 3 and 5 days for yeasts and molds, respectively, the colonies were counted individually, based on the macromorphological characteristics. From the aqueous extract, $\mathrm{pH}$ measurements were also performed. The $\mathrm{pH}$ of the samples was measured with an electrode (Tekna T-1000) after 30 min of rest. The analysis of ammoniacal nitrogen $\left(\mathrm{NH}_{3}-\mathrm{N}\right)$ was carried out according to method 941.04 (AOAC 1990).

For the quantification of organic acids (lactic, acetic, propionic, butyric, isobutyric, valeric, and isovaleric), $25 \mathrm{~g}$ of silage were solubilized in $300 \mathrm{ml}$ of deionized water and homogenized in a Stomacher homogenizer (MARCONI-MA 440/CF). Subsequently, the filtrate was extracted, and $1 \mathrm{~mL}$ of the aliquot was removed for gas chromatography. The gas chromatograph used was an Agilent 7890A, equipped with a flame ionization detector (7683B) and fused silica capillary column - J \& W 19091F-112 (Agilent Technologies, Santa Clara, USA). The total organic acids (TOA) were determined from the sum of all the evaluated acids. The relationship between lactic and acetic acid (LA:AA) was determined by dividing the quantity of lactic acid by that of acetic acid.

\section{Chemical composition}

For the determination of the chemical composition, the samples were weighed and pre-dried in a forced air circulation oven $\left(55^{\circ} \mathrm{C} / 72 \mathrm{~h}\right)$, and then milled in a Willey-type (STARFT-80/2) knife mill with a sieve screen of pore diameter 1 $\mathrm{mm}$. The evaluation of dry matter (DM; official method 934.01), organic matter (OM; official method 923.03), and crude protein (CP; official method 978.04) content were performed according to the official methods of AOAC (1990). The levels of neutral detergent insoluble nitrogen (NDIN) and acid detergent insoluble nitrogen (ADIN) were determined according to the procedures described by Licitra et al. (1996).
The content of the ethereal extract (EE) was determined in a fat extractor (Model: XT10- Ankom ${ }^{\oplus}$; Method: Am-5-04; AOCS 2009). Before ensiling, the grass and meal were evaluated for characterization of the material (Table 1).

The levels of neutral detergent insoluble fiber (NDF), acid detergent insoluble fiber (ADF), and lignin (LIG) were determined in accordance with the official method 973.18 (AOAC 1990). Cellulose (CEL) was determined by the difference between the ADF and LIG, and hemicellulose (HCEL) by the difference between the NDF and ADF. The content of the non-fibrous carbohydrates (NFC) was calculated according to Detmann and Valadares Filho (2010).

\section{Statistical analysis}

The microbiological composition data were transformed to $\log _{10}$ for statistical presentation and analysis. The data obtained for the losses, fermentative characteristics, and chemical composition of the treatments and control were submitted to simple linear regression analyses. For all statistical analyses, SAS ${ }^{\circ}$ was used (Statistical Analysis System 2009), adopting 5\% as the level of significance. The applied mathematical model was: $Y_{i j}=\mu+T_{i j}+e_{i j}$, where $Y_{i j}=$ observation $j$, referring to each inclusion level of patauá meal (i); $\mu$ = overall average; $T_{i j}$ $=$ effect of the inclusion level of patauá meal; and $\mathrm{e}_{\mathrm{ij}}=$ error associated with each observation.

\section{RESULTS}

The inclusion of patauá meal in elephant grass silage did not significantly change the GL, DMR, molds and yeast counts, $\mathrm{pH}, \mathrm{NH}_{3}-\mathrm{N}$, or concentrations of organic acids (lactic, acetic, propionic, butyric, isobutyric, valeric, isovaleric, total organic acids, and LA:AA) (Table 2). EL decreased significantly with increased concentration of patauá meal. HCEL was not significantly altered by the concentration of patauá meal (Table 3). DM, OM, CP, NDIN, ADIN, EE, LIG, and NFC increased significantly, while NDF, ADF, and CEL decreased with increased concentration of patauá meal.

\section{DISCUSSION}

Quantitative and qualitative losses of forage primarily occur during storage in the silo, mainly due to the production of effluents (Borreani et al. 2018). Some of the nutrients of the forage are lost through the effluents, especially those present within the cells (Gebrehanna et al. 2014). Our results showed that patauá meal was effective in reducing the effluent losses of silage, due to its high DM content, supporting Wilkinson and Rinne (2018) in that forages with a DM content between $28 \%$ and $35 \%$ have low effluent production.

Although the concentration of acetic and propionic acids was not modified by the inclusion of pataua meal, the contents of these acids may have been effective in inhibiting the development of molds and yeasts, confirmed by their low 
Table 2. Fermentative characteristics and losses of elephant grass (Pennisetum purpureum) with different inclusion levels of patauá (Oenocarpus bataua) meal. $R^{2}=$ determination coefficient. Values are the mean \pm SE. NS $=$ non significant.

\begin{tabular}{|c|c|c|c|c|c|c|c|}
\hline \multirow[b]{2}{*}{ Parameter } & \multicolumn{5}{|c|}{ Levels of inclusion of patauá meal (\%FM) } & \multirow{2}{*}{$\begin{array}{l}\text { Regression } \\
\text { equation }\end{array}$} & \multirow{2}{*}{$R^{2}$} \\
\hline & Control & $7 \%$ & $14 \%$ & $21 \%$ & $28 \%$ & & \\
\hline Gass loss (\%DM) & $0.10 \pm 0.03$ & $0.11 \pm 0.03$ & $0.11 \pm 0.02$ & $0.08 \pm 0.04$ & $0.10 \pm 0.03$ & $\mu=0.10$ & NS \\
\hline Dry matter recovery (\%DM) & $87.19 \pm 2.42$ & $84.23 \pm 1.53$ & $81.20 \pm 0.90$ & $89.23 \pm 2.55$ & $83.95 \pm 3.16$ & $\mu=85.16$ & NS \\
\hline Effluent loss (kg/t FM) & $78.10 \pm 2.73$ & $65.96 \pm 1.80$ & $59.70 \pm 4.43$ & $27.70 \pm 8.25$ & $4.16 \pm 2.29$ & $Y=84.35-2.66 x$ & $0.94^{* *+*}$ \\
\hline Molds (log UFC. $\left.g^{-1}\right)$ & $2.26 \pm 0.16$ & $0.98 \pm 0.27$ & $2.14 \pm 0.17$ & $2.35 \pm 0.15$ & $1.88 \pm 0.48$ & $\mu=1.92$ & NS \\
\hline Yeast (log UFC.g-1) & $<2.0$ & $<2.0$ & $<2.0$ & $<2.0$ & $<2.0$ & - & NS \\
\hline $\mathrm{pH}$ & $4.04 \pm 0.12$ & $4.18 \pm 0.14$ & $4.39 \pm 0.21$ & $4.11 \pm 0.16$ & $4.03 \pm 0.23$ & $\mu=4.15$ & NS \\
\hline Amoniacal nitrogen (\% TN) & $5.01 \pm 0.47$ & $3.91 \pm 0.75$ & $5.27 \pm 0.22$ & $4.20 \pm 0.32$ & $4.27 \pm 0.77$ & $\mu=4.53$ & NS \\
\hline Lactic acid (\% DM) & $4.66 \pm 1.37$ & $2.33 \pm 1.28$ & $4.76 \pm 2.06$ & $5.90 \pm 1.57$ & $2.97 \pm 0.82$ & $\mu=4.12$ & NS \\
\hline Acetic acid (\% DM) & $2.24 \pm 0.79$ & $3.58 \pm 0.96$ & $2.31 \pm 0.45$ & $3.06 \pm 0.80$ & $1.23 \pm 0.37$ & $\mu=2.48$ & NS \\
\hline Propionic acid (\% DM) & $0.00 \pm 0.00$ & $0.38 \pm 0.38$ & $0.86 \pm 0.86$ & $0.89 \pm 0.89$ & $0.17 \pm 0.17$ & $\mu=0.46$ & NS \\
\hline Butyric acid (\% DM) & $1.59 \pm 1.17$ & $1.75 \pm 1.75$ & $1.34 \pm 0.94$ & $2.08 \pm 1.50$ & $2.27 \pm 1.40$ & $\mu=1.81$ & NS \\
\hline Isobutyric acid (\% DM) & $0.00 \pm 0.00$ & $0.00 \pm 0.00$ & $1.30 \pm 0.76$ & $0.12 \pm 0.12$ & $0.22 \pm 0.14$ & $\mu=0.32$ & NS \\
\hline Valeric acid (\% DM) & $0.20 \pm 0.20$ & $0.23 \pm 0.14$ & $0.62 \pm 0.39$ & $0.20 \pm 0.12$ & $0.54 \pm 0.18$ & $\mu=0.36$ & NS \\
\hline Isovaleric acid (\% DM) & $0.20 \pm 0.20$ & $0.00 \pm 0.00$ & $0.47 \pm 0.35$ & $0.10 \pm 0.10$ & $0.23 \pm 0.13$ & $\mu=0.20$ & NS \\
\hline Total organic acids (\% DM) & $8.43 \pm 0.92$ & $8.27 \pm 1.32$ & $11.67 \pm 3.54$ & $12.35 \pm 3.42$ & $7.63 \pm 1.74$ & $\mu=9.67$ & NS \\
\hline LA:AA & $3.61 \pm 1.49$ & $1.24 \pm 0.71$ & $2.20 \pm 0.79$ & $3.09 \pm 1.64$ & $3.93 \pm 1.84$ & $\mu=2.81$ & NS \\
\hline
\end{tabular}

*There was no yeast growth in the evaluated silages. For the non-significant (NS) regression equations, the mean ( $\mu$ ) of treatments is informed. ${ }^{* * *}$ Significant at $p<0.001$.

Table 3. Chemical composition of elephant grass (Pennisetum purpureum) with different inclusion levels of patauá (Oenocarpus bataua) cake. $R^{2}=$ determination coefficient. Values are the mean \pm SE. NS = non significant.

\begin{tabular}{|c|c|c|c|c|c|c|c|}
\hline \multirow[b]{2}{*}{ Parameter } & \multicolumn{5}{|c|}{ Levels of inclusion of patauá meal } & \multirow{2}{*}{$\begin{array}{l}\text { Regression } \\
\text { equation }\end{array}$} & \multirow{2}{*}{$\mathrm{R}^{2}$} \\
\hline & Control & $7 \%$ & $14 \%$ & $21 \%$ & $28 \%$ & & \\
\hline Dry matter (\% FM) & $18.12 \pm 0.48$ & $21.98 \pm 0.36$ & $25.63 \pm 0.19$ & $31.74 \pm 0.59$ & $34.98 \pm 0.12$ & $Y=17.79+0.62 x$ & $0.98^{* * * *}$ \\
\hline Organic matter (\% DM) & $94.40 \pm 0.08$ & $94.48 \pm 0.07$ & $95.33 \pm 0.06$ & $95.02 \pm 0.05$ & $95.86 \pm 0.16$ & $Y=94.33+0.06 x$ & $0.83^{* \cdots+}$ \\
\hline Crude protein (\% DM) & $8.07 \pm 0.32$ & $8.64 \pm 0.24$ & $8.74 \pm 0.26$ & $9.27 \pm 0.27$ & $9.45 \pm 0.17$ & $Y=8.16+0.05 x$ & $0.46^{* *}$ \\
\hline Neutral insoluble detergent (\% TN) & $14.23 \pm 0.53$ & $15.87 \pm 0.60$ & $25.37 \pm 0.89$ & $25.16 \pm 1.46$ & $24.64 \pm 0.58$ & $Y=13.03+2.14 x$ & $0.48^{* \cdots}$ \\
\hline Acid insoluble detergent (\% TN) & $11.51 \pm 1.27$ & $12.01 \pm 0.87$ & $17.82 \pm 0.67$ & $15.92 \pm 1.26$ & $18.76 \pm 0.73$ & $Y=11.08+1.76 x$ & $0.30^{* * * *}$ \\
\hline Ether extract (\% DM) & $1.29 \pm 0.02$ & $2.13 \pm 0.04$ & $4.04 \pm 0.09$ & $4.24 \pm 0.12$ & $4.67 \pm 0.26$ & $Y=1.44+0.14 x$ & $0.90^{* * * *}$ \\
\hline Neutral detergent fiber (\% DM) & $70.35 \pm 0.81$ & $65.06 \pm 0.27$ & $61.91 \pm 0.60$ & $56.60 \pm 0.27$ & $54.95 \pm 0.68$ & $Y=69.62-0.56 x$ & $0.94^{* * * *}$ \\
\hline Acid detergent fiber (\% DM) & $48.71 \pm 3.14$ & $40.58 \pm 1.25$ & $37.87 \pm 1.04$ & $36.49 \pm 0.69$ & $29.09 \pm 0.94$ & $Y=47.22-0.61 x$ & $0.73^{\cdots *}$ \\
\hline Hemicellulose (\% DM) & $18.18 \pm 2.94$ & $21.13 \pm 1.31$ & $20.61 \pm 0.64$ & $16.70 \pm 0.86$ & $22.62 \pm 0.42$ & $\mu=23.22$ & NS \\
\hline Cellulose (\% DM) & $43.15 \pm 3.28$ & $32.21 \pm 1.34$ & $29.18 \pm 0.67$ & $27.08 \pm 0.73$ & $18.32 \pm 0.94$ & $Y=40.95-0.78 x$ & $0.78^{* \cdots+}$ \\
\hline Lignin (\% DM) & $5.56 \pm 0.19$ & $8.37 \pm 0.17$ & $8.68 \pm 0.40$ & $9.42 \pm 0.46$ & $10.77 \pm 0.12$ & $Y=6.27+0.16 x$ & $0.79^{* * *}$ \\
\hline Non fibrous carbohydrates (\% DM) & $18.14 \pm 0.55$ & $22.24 \pm 0.72$ & $24.07 \pm 0.88$ & $29.18 \pm 0.53$ & $29.70 \pm 0.72$ & $Y=15.18+0.43 x$ & $0.88^{* * *}$ \\
\hline
\end{tabular}

${ }^{*}$ For the non-significant (NS) regression equations, the mean $(\mu)$ of all treatments is informed. ${ }^{* *}$ significant at $p<0.01$; ${ }^{* *}$ significant at $p<0.001$.

counts in all silages. Notably, both acids present antifungal effects (Kung et al. 2018) and pass through the cell membrane of these microorganisms when the $\mathrm{pH}$ of these acids is lower than the $\mathrm{pKa}$ ( 4.75 and 4.87 , respectively). The highest $\mathrm{pH}$ in our silages was 4.4, below the pKa for both acids. Under these conditions, the acids are in the non-dissociated form, which will cause the release of $\mathrm{H}^{+}$ions inside the fungi, reducing the internal $\mathrm{pH}$ of the microorganism, thus causing a collapse in its metabolism (Walker 1998).
The long storage period of the silages may also have influenced the production of acetic acid and, consequently, the mold and yeast count at the opening of the silo. $\mathrm{Li}$ and Nishino (2013) observed an increase in the acetic acid content with the storage time of Tanzania grass silage. In addition to the effects of acetic acid on these microorganisms, the soluble carbohydrate content probably decreased during the storage period, as these compounds are rapidly consumed by the microorganisms present in the silage during the first days 
of storage. Thus, in silages stored for prolonged periods, this substrate may have been insufficient to promote the growth of yeasts and molds.

The $\mathrm{pH}$ of all our experimental silages, including the control, remained around 4.1 to 4.4 , within the range normally observed (4.3 to 4.7) for grass silages that show a suitable fermentation (Kung et al. 2018). This may also be related to the high levels of LA present in silages. All silages presented values of $\mathrm{NH}_{3}-\mathrm{N}$ below $12 \%$, which is considered the maximum limit for the proper conservation of grass silage (Kung et al. 2018). This indicates low proteolytic activity of the nitrogen compounds in the silages (true protein, peptides, amino acids, amines, and amides), which is related to the low $\mathrm{pH}$ values observed. The fermentative characteristics thus indicated that both the control and treatment silages were properly fermented.

The increase in the DM content of the silages is justified by the inclusion of the pataua meal, which had a high DM content (89.6\%). Similarly, the OM content of the silages increased due to the OM content of the patauá meal (97.4\%). The mean CP contents were above the minimum content of $7 \%$ (\% of the total diet) required to prevent ruminant feed consumption and effects on fermentation of structural carbohydrates by the microbial flora of the rumen (Lazzarini et al. 2009).

The increase in the content of ethereal extract in the silages containing patauá meal did not exceed the limit of $10 \%$, the maximum limit considered so that ruminates do not reduce the intake of dry matter (Palmquist and Mattos 2011). Fatty acids can reduce rumen fermentation and affect animal performance (Carvalho et al. 2016) by influencing ruminal microorganisms.

Most of the nitrogen compounds within the forage are attached to the cell walls in the form of NDIN and ADIN (Oliveira et al. 2010). With the inclusion of patauá meal, these compounds increased, as the NDIN and ADIN of the meal were transferred to the elephant grass silage. The reduction in the NDF and ADF with increasing patauá levels was possibly due to the reduction in the cellulose content of the silages, as these constituents were present in low levels in the patauá meal. NDF levels in the control, and in the $7 \%$, and $14 \%$ treatments were above the $55 \%-60 \%$ recommended by Van Soest (1994). NDF is an important regulator of intake due to its slow degradation and reduced passage rate, which has a negative correlation with food intake. NDF values above $60 \%$ limit the dry matter intake due to ruminal filling, because the fiber exerts pressure on the rumen wall, triggering physiological responses that activate the rumination process, causing the animal to reduce its intake (Geron et al. 2012).

The higher percentages of ADF in the control and 7\% treatment may have been due to their lower DM contents. Thus, greater loss of soluble components was caused by the effluents, proportionally increasing the components of the fibrous fraction. The remaining residue of the sample after $\mathrm{ADF}$ determination is used for sequential estimation of lignin, cutin, cellulose, and indigestible nitrogen, being directly related to the digestibility of the food (Van Soest 1994). If the ADIN concentration is high in the ADF, total nitrogen digestibility in the gastrointestinal tract of the animal decreases (Machacek and Kononoff 2009).

The increased lignin values can be explained by the lignin content of the patauá meal, resulting in an increase in the content in the silages. Lignin is a chemical component present in NDF that is related to the higher frequency of low nutrient digestibility (Grant and Ferraretto 2018). The nutritive value of the food is determined by two factors: the proportion of plant cell wall and degree of lignification, the lignified part of the fiber being resistant to the action of enzymes secreted by ruminal microorganisms (Silva et al. 2016).

The reduction in cellulose content is associated with the lower content of this component in the pataua meal. Notably, both hemicellulose and cellulose occupy more space in the gastrointestinal tract, because cellulose presents slow degradability and hemicellulose does not have a constant digestibility and is partially available, like cellulose (Macedo Júnior et al. 2007).

Due to the increase in NFC with the inclusion of patauá meal, there was an increase in the concentrations of soluble sugars that can be used as substrates by bacteria of the genus Lactobacillus, which create desirable fermentation in the silage (Van Soest 1994). As patauá meal proved to be efficient in reducing effluent production, it is a potential nutrient additive, mainly in silages with high moisture, as is the case in tropical grasses. However, studies that evaluate the parameters of silage digestibility and animal intake/ performance of silage containing patauá meal are necessary to further evaluate the potential of this additive in elephant grass silage.

\section{CONCLUSIONS}

Our results indicate that patauá meal can be used as a moistureabsorbing additive in elephant grass silages, achieving a potential reduction of effluent loss when its inclusion is tested up to $28 \%$. Moreover, there was an increase in non-fibrous carbohydrates with the inclusion of the additive. The addition of the meal did not alter the fermentative characteristics of the silages.

\section{ACKNOWLEDGMENTS}

The authors thank Amazon Oil for contributing to the research, through the supply of pataua meal; the undergraduate and graduate students from Grupo de Estudos em Ruminantes e Forragicultura da Amazônia (GERFAM) for their technical support; Coordenação de Aperfeiçoamento de Pessoal de Nível 
Superior - CAPES (Brazil) (Procad nr. 71/2013) for financial assistance; and Conselho Nacional de Desenvolvimento Científico e Tecnológico - CNPq (Brazil) for providing scholarships to the first and second authors.

\section{REFERENCES}

Alvares, C.A.; Stape, J.L.; Sentelhas, P.C.; Gonçalves, J.L.M.; Sparovek, G. 2014. Köppen's climate classification map for Brazil. Meteorologische Zeitschrift, 22: 711-728.

AOAC. 1990. Official Methods of Analysis of the AOAC. 15th ed. Association of Official Analytical Chemists. Washington DC, $1230 \mathrm{p}$.

AOCS. 2009. Official Methods and Recommended Practices of the AOCS. 6th ed. American Oil Chemists Society, Washington, $1200 \mathrm{p}$.

Bernardes, T.F.; Daniel, J.L.P.; Adesogan, A.T.; McAllister, T.A.; Drouin, P.; Nussio, L.G.; Huhtanen, P.; Tremblay, G.F.; Bélanger, G.; Cai, Y. 2018. Silage review: Unique challenges of silages made in hot and cold regions. Journal of Dairy Science, 101: 4001-4019.

Borreani, G.; Tabacco, E.; Schmidt, R.J.; Holmes, B.J.; Muck, R.E. 2018. Silage review: Factors affecting dry matter and quality losses in silages. Journal of Dairy Science, 101: 3952-3979.

Carvalho, I.P.C.; Fiorentini, G.; Berndt, A.; Castagnino, P.S.; Messana, J.D.; Frighetto, R. T.S.; Reis, R.A; Berchielli, T.T. 2016. Performance and methane emissions of Nellore steers grazing tropical pasture supplemented with lipid sources. Revista Brasileira de Zootecnia, 45: 760-767.

Daniel, J.L.P.; Bernardes, T.F.; Jobim, C.C.; Schmidt, P.; Nussio, L.G. 2019. Production and utilization of silages in tropical areas with focus on Brazil. Grass and Forage Science. 2019: 1-13.

Detmann, E.; Valadares Filho, S.C. 2010. On the estimation of non-fibrous carbohydrates in feeds and diets. Arquivo Brasileiro de Medicina Veterinária e Zootecnia, 62: 980-984.

Grant, R.J.; Ferraretto, L.F. 2018. Silage review: Silage feeding management: Silage characterísticas and dairy cow feeding behavior. Journal of Dairy Science, 101: 4111- 4121.

Gebrehanna, M.M.; Gordon, R.J.; Madani, A.; Vanderzaag, A.C.; Wood, J.D. 2014. Silage effluent management: A review. Journal of Environmental Management, 143: 113-122.

Geron, L.J.V.; Mexia, A.A.; Garcia, J.; Zeoula, L.M.; Garcia, R.R.F. Moura, D.C. 2012. Desempenho de cordeiros em terminação suplementados com caroço de algodâo (Gossypium hirsutum 1.) e grão de milho moído (zea mays 1.). Archives of Veterinary Science, 17: 34-42.

Hidalgo, P.S.P.; Nunomura, R.C.S.; Nunomura, S.M. 2016. Plantas oleaginosas amazônicas: Química e atividade antioxidante de patauá (Oenocarpus bataua Mart.). Revista Virtual de Química, 8: 130-140.

Jobim, C.C; Nussio, L.G; Reis, R.A; Schmidt, P. 2007. Avanços metodológicos na avaliação da qualidade da forragem conservada. Revista Brasileira de Zootecnia, 36: 101-119.

Kung, L.; Shaver, R.D.; Grant, R.J.; Schmidt, R.J. 2018. Silage review: Interpretation of chemical, microbial and organoleptic components of silages. Journal of Dairy Science, 101: 4020-4033.
Lazzarini, I.; Detman, E.; Sampaio, C.B.; Paulino, S.C.V.F.; Souza, M.A.; Oliveira, F.A. 2009. Intake and digestibility in cattle fed low-quality tropical forage and suplemented with nitrogenous compounds. Revista Brasileira de Zootecnia, 38: 2021-2030.

Lima Júnior, D.M.; Rangel, A.H.N.; Urbano, S.A.; Oliveira, J.P.F.; Maciel, M.V. 2014. Silagem de gramíneas tropicais nãograníferas. Agropecuária Cientifica no Semiárido, 10: 1-11.

Li, Y.; Nishino, N. 2013. Effects of ensiling fermentation and aerobic deterioration on the bacterial community in italian ryegrass, guinea grass, and whole-crop maize silages stored at high moisture content. Asian-Australas Journal Animal Science, 26: 1304-1312.

Licitra, G.; Hernández, T.M.; Van Soest, P.J. 1996. Standardization of procedures for nitrogen fractionation of ruminant feeds. Animal Feed Science and Technology, 57: 347-358.

Macedo Júnior, G.L.; Zanine, A.M.; Borges, I.; Pérez, J.R.O. 2007. Qualidade da fibra para a dieta de ruminantes. Ciência Animal, 17: 7-17.

Machacek, K.J.; Kononoff, P.J. 2009. The relationship between acid detergent insoluble nitrogen and nitrogen digestibility in lactating dairy cattle. The Professional Animal Scientist, 25: 701-708.

Menezes, B.P.; Rodrigues, L.S.; Lourenço Júnior, J.B.; Silva, A.G.M.; Andrade, S.J.T.; Silva, J.A.R.; et al. 2016. Intake, digestibility, and nitrogen balance of rations containing different levels of murumuru meal in sheep diets. Semina: Ciências Agrárias, 37: 415-427.

Oliveira, L.B.; Pires, A.J.V.; Carvalho, G.G.P.; Ribeiro, L.S.O.; Almeida, V.V.; Peixoto, C.A.M. 2010. Perdas e valor nutritivo de silagens de milho, sorgo-sudão, sorgo forrageiro e girassol. Revista Brasileira de Zootecnia, 39: 61-67.

Palmquist, D.L.; Mattos, W.R.S. 2011. Metabolismo de lipídios. In: Berchielli, T.T.; Pires, A.V.; Oliveira, S. G. (Ed.). Nutrição de Ruminantes. 2nd. ed. Fundação de Amparo e Apoio a Pesquisa, Jaboticabal, p.299-322.

Ramalho, H.F.; Suarez, P.A.Z. 2013. A química dos óleos e gorduras e seus processos de extraçáo e refino. Revista Virtual de Química, 5: 2-15.

Rêgo, M.M.T.; Neiva, J.N.M.; Rêgo, A.C.; Candido, M.J.D.; Carneiro, M.S S.; Lobo, R.N.B. 2010. Chemical and bromatological characteristics of elephant grass silages containing a mango by-product. Revista Brasileira de Zootecnia, 39: 81-87.

Ribeiro, L.S.O.; Pires, A.J.V.; Carvalho, G.G.P.; Pereira, M.L.A.; Santos, A.B.; Rocha, C.L. 2014. Características fermentativas, composição química e fracionamento de carboidratos e proteínas de silagem de capim - elefante emurchecido ou com adiçáo de torta de mamona. Semina: Ciências Agrárias, 35: 1447-1462.

Rodrigues, A.M.C.; Darnet, S.H.; Silva, L.H.M. 2010. Fatty acid profiles and tocoferol contents of buriti (Mauritia flexuosa), patawa (Oenocarpus bataua), tucuma (Astrocaryum vulgare), mari (Poraqueiba paraensis), and inaja (Maximiliana maripa) fruits. Journal of the Brazilian Chemical Society, 21: 2000-2004.

Santos, I.A.P.; Domingues, F.N.; Rêgo, A.C.; Souza, N.S.S; Bernardes, T.F.; Barata, Z.R.P.; Moraes, C.M. 2014. Palm kernel meal as additive in the elephant-grass silage. Revista Brasileira de Saúde e Produção Animal, 15: 592 - 603. 
SAS. 2009. Statistical Analysis Sistem. SAS/STAT 9.2 User's Guide. SAS Institute Inc, Cary NC.

Seixas, F.R.F.; Taynara, S.V.; Cintra, D.E.C. 2015. Caracterização físico-química e fração lipídica do patauá proveniente da aldeia baixa verde no município de Alto Alegre dos Parecis-RO. Revista Cientifica da UNESC, 13: 95-103.

Silva, V.L.; Borges, I.; Araújo, A.R.; Costa, H.H.A.; Filho, F.M.A.; Frutuoso, F.I.A.; Silva, R.H.P.; Ancântara, P.B.X. 2016. Efeito do tratamento químico sobre a digestibilidade de volumosos e subprodutos agroindustriais. Acta Kariri Pesquisa e Desenvolvimento, 1: 29-37.

Souza, R.S.; Andrade, S.J.; Costa, S.S. 2012. Effect of the harvest date on the chemical composition of patauá (Oenocarpus batua Mart.) fruits from a forest reserve in the Brazilian Amazon. International Journal of Agronomy, 2012: 1-6.

Tomaz, P.K.; Araujo, L.C.; Sanches, L.A.; Araujo, S.N.S.; Lima, T.O.; Lino, A.A.; Ferreira, E.M. 2018. Effect of sward height on the fermentability coefficient and chemical composition of Guinea grass silage. Grass and Forage Science, 73: 588-598.
Van Cleef, E.H.C.B.; Filho, J.C.S.; Júnior, A.P.N.; Pardo, R.M.P.; Rêgo, A.C.; Gonçalves, J.S. 2012. Chemical composition and fermentation characteristics of elephant grass silage with biodiesel industry co-product. Ciência Rural, 24: 718 - 723.

Van Soest, P.J. 1994. Nutritional ecology of the ruminant. 2nd. ed. Comstock Publishing Associates, Ithaca, 476p.

Walker, G.M. 1998. Yeast physiology and biotechnology. Wiley Editorial Offices, London, 362p.

Wilkinson, J.M; Rinne, M. 2018. Review. Highlights of progress in silage conservation and future perspectives. Grass and Forage Science, 73: 40-52.

RECEIVED: $30 / 04 / 2019$

ACCEPTED: 07/05/2020

ASSOCIATE EDITOR: Antonio Rodrigues Fernandes 